\title{
PERSEPSI DAN TINGKAT KECEMASAN PENGENDARA PADA KONDISI NEW NORMAL
}

\author{
Bambang Istiyanto, Sunaryo, Ngakan Made Sidan Arnawa, Dynes Rizky Navianti* \\ Manajemen Logistik, Politeknik Transportasi Darat Bali. Jl. Cempaka Putih, Desa Samsam, Kec.Kerambitan, \\ Kab. Tabanan - Bali, Indonesia 80582 \\ *dynes@poltradabali.ac.id
}

\begin{abstract}
ABSTRAK
Penyebaran virus corona di Indonesia yang memiliki peringkat tinggi dan tidak dapat diprediksi kapan berakhir. Penyebaran tersebut terlihat juga dari angkat tingkat penyebaran dan angka kematian di wilayah di Indonesia diantaranya Provinsi DKI Jakarta dan Provinsi Jawa Timur. Mengacu pada informasi di kedua provinsi tersebut, tak terlewatkan juga potensi penyebaran pun juga meningkat pada Provinsi Bali mengingat wilayah tersebut merupakan pusat pariwisata. Kondisi itu dapat meningkatkan kecemasan pada masyarakat, sehingga mobilitasnya pun akan juga terhambat. Adanya asumsi kendala mobilitas itu, penelitian ini menghasilkan hubungan bagaimana persepsi masyarakat khususnya perilaku para pengendara di kondisi new normal saat ini di Provinsi Bali. Keduanya memiliki hubungan positif secara signifikan dengan nilai signifikansi ebesar 0,000. Hal ini menunjukkan bahwa kecemasan membentuk persepsi para pengendara. Sebagian besar pengendara dimaksud memiliki jenis kelamin laki-laki dengan persentase $85 \%$ yang merasa cemas saat berkendara.
\end{abstract}

Kata kunci: bali; kecemasan; pengendara; penyebaran; persepsi

\section{RIDER PERCEPTION AND ANXIETY LEVEL IN NEW NORMAL CONDITIONS}

\begin{abstract}
The spread of the corona virus in Indonesia which has a high ranking and it cannot be predicted when it will end. This spread can also be seen from the increase in the level of spread and mortality in areas in Indonesia, including DKI Jakarta and East Java Provinces. Referring to the information in the two provinces, it is not unmistakable that the potential for dissemination has also increased in Bali Province considering that the region is a center of tourism. This condition can increase anxiety in the community, so that their mobility will also be hampered. With the assumption of mobility constraints, this research results in a relationship to how the community's perceptions, especially the behavior of motorists, in the current new normal conditions in Bali Province. Both have a significant positive relationship with a significance value of 0.000. This suggests that anxiety shapes motorists' perceptions. Most of the drivers mentioned are male with a percentage of $85 \%$ who feel anxious when driving.
\end{abstract}

Keywords: anxiety; bali; perception; rider; spread

\section{PENDAHULUAN}

Virus corona diidentifikasi sebagai penyebab kematian pneumonia pada Desember 2019 lalu di Cina. Virus ini berkembang sangat pesar diseluruh penjuru dunia temasuk Indonesia. Berikut ini adalah data penyebaran virus corona di Indonesia berdasarkan informasi yang didapat dari WHO. Gambar 1 menunjukkan bahwa 80.000 lebih kasus yang telah dikonfirmasi di Indonesia mengenai virus corona. Tren tersebut mengalami peningkatan yang pesat dalam kurun waktu lima bulan yang terhitung sejak awal maret.

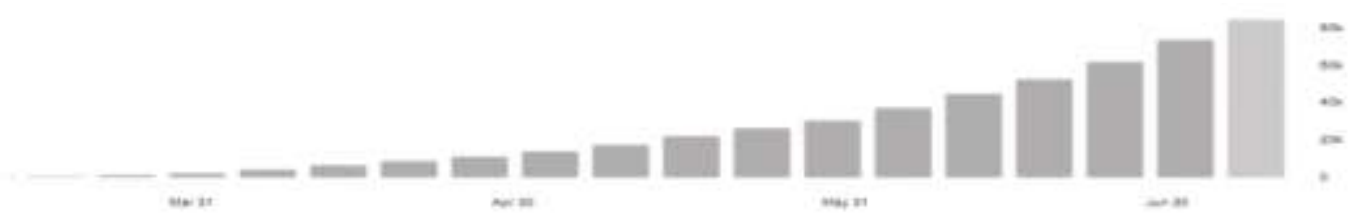

Gambar 1. Data tren konfirmasi kasus corona di Indonesia 


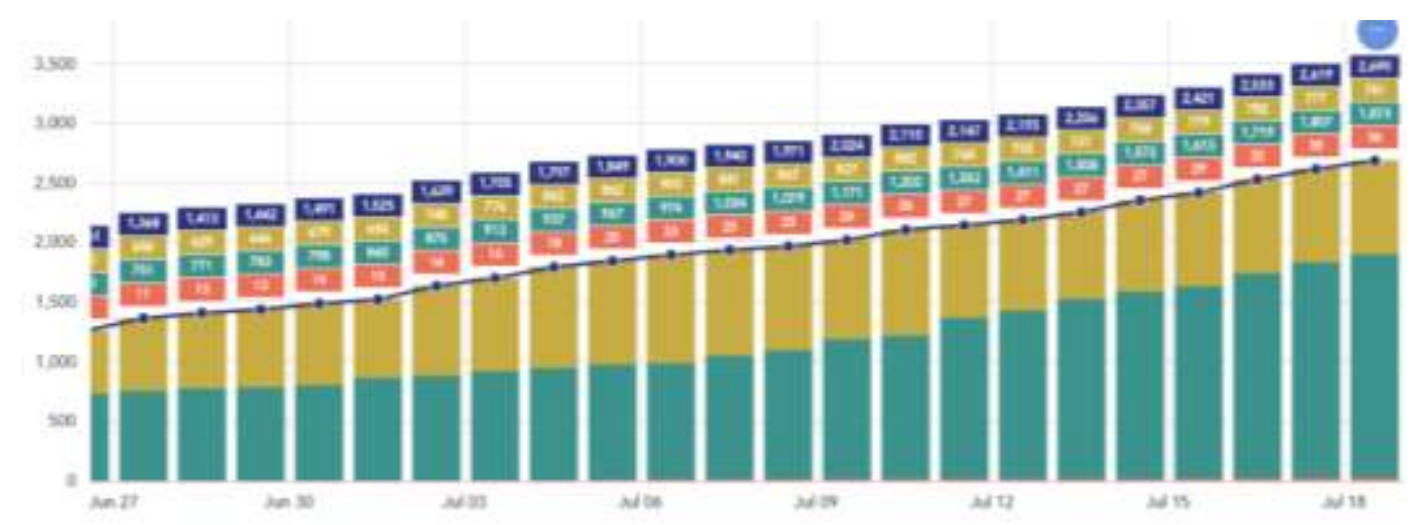

Gambar 2. Tren kasus virus corona di Bali, Indonesia

Gambar 2 adalah tren dari sebaran virus corona selama hampir tiga pekan di Provinsi Bali. Mengantisipasi dan mengurangi jumlah penderita virus corona di Bali sebenarnya sudah dilakukan di seluruh daerah termasuk Bali, diantaranya dengan misalnya, (1) batasan kontak dan aturan jarak, (2) penutupan sementara perusahaan perdagangan dan jasa, serta, keahlian memasak, bisnis hotel, dan fasilitas rekreasi, (4) pembatasan perjalanan dalam negara dan khususnya untuk perjalanan yang tidak penting, atau (5) kewajiban untuk kenakan penutup mulut dan hidung saat menggunakan transportasi umum. Langkah-langkah ini memiliki dampak signifikan pada ekonomi global bahwa pertumbuhannya adalah lambat. Lebih jauh lagi pada kesejahteraannya. Kebijakan New Normal adalah sebuah strategi yang dirancang untuk menjaga kestabilan perekonomian dan kesejahteraan masyarakat dalam pencegahan penyebaran virus corona. Kebijakan tersebut juga untuk mencegah potensi risiko kematian pada masyarakat. Informasi terkait kebenaran jumlah ini perlu juga jadi perhatian, karena masih ada ditemukan berita-berita yang masih simpang siur atau hoaks, sehingga menimbulkan kecemasan di masyarakat.

Upaya menghadapi situasi yang tidak pasti dapat meningkatkan tingkat kecemasan orang, terutama ketika masyarakat cemas adanya potensi risiko kematian yang disebabkan oleh virus corona. Tingkat kecemasan menyebabkan individu yang sehat maupun yang rentan terhadap covid, dapat melakukan perilaku protektif (Shigemura et al., 2020). Sekitar seperempat dari mahasiswa menunjukkan setidaknya terdapat kecemasan tingkat ringan terhadap wabah COVID-19 (Cao et al., 2020). Diharapkan dengan adanya rasa takut terhadap COVID-19, akan berdampak besar pada kesehatan mental masyarakat (Torales et al., 2020).

\section{METODE}

Variabel adalah segala sesuatu yang dapat menjadi objek dan subjek penelitian (Indriantoro, 1999:26). Variabel-variabel yang akan diteliti adalah variabel dependen penelitian ini yaitu persepsi pengendara yang terdiri dari tiga dimensi yaitu: (1)kepatuhan mengendarai (penggunaan masker dan sarung tangan, jaga jarak atau physical distansing); (2)keselamatan berkendara (penggunaan seatbelt atau helm); (3)pemilihan moda transportasi (kendaraan pribadi atau angkutan umum).Variabel independen dalam penelitian ini adalah tingkat kecemasan yang terdiri dari tiga dimensi, yaitu: (1)pengetahuan tentang gejala, metode pencegahan, manajemen dan layanan konsultasi ketika terinfeksi; (2)tingkat ketakutan; (3)Pengujian instrument dimaksudkan untuk mengukur kesahihan (validitas) dan keandalan (reliabilitas) instrument penelitian. Pengujian dilakukan dengan menyebarkan kuesioner pada responden dan hasil kuesioner tersebut digunakan untuk menguji validitas dan reliabilitas atat pengukur dalam penelitian ini. Uji Kesahihan (Validitas) digunakan untuk menguji sejauh mana suatu daftar pertanyaan dapat mengukur data yang dibutuhkan dalam penelitian. Uji 
validitas dilakukan dengan mengkorelasikan skor yang diperoleh dari masing- masing item dengan skor total dengan menggunakan teknik korelasi product moment (Hadi, 2001:44). Uji reliabilitas menggunakan metode internal consistence reliability atau reliabilitas internal dengn teknik split half atau belah dua dari Spearman Brown. Teknik ini digunakan untuk menguji apakah daftar pertanyaan saling berkaitan dalam satu pola yang konsisten.

Pengujian hipotesis penelitian dilakukan dengan pendekatan Structural Equation Modeling (SEM) dengan menggunakan software Partial Least Square (PLS). PLS adalah model persamaan Structural Equation Modeling (SEM) yang berbasis komponen atau varian (variance). Menurut Ghozali (2011) SEM yang berbasis kovarian umumnya menguji kausalitas/teori sedangkan PLS lebih bersifat predictive model. PLS merupakan metode analisis yang powerfull karena tidak didasarkan pada banyaknya asumsi (Worl dalam Ghozali, 2011). Data tidak harus berdistribusi normal, sampel tidak harus besar. Selain dapat digunakan untuk mengkonfirmasi teori, PLS juga dapat digunakan untuk menjelaskan ada tidaknya hubungan antar variabel laten. PLS dapat sekaligus menganalisis konstruk yang dibentuk dengan indikator refleksif dan formatif. Hal ini tidak dapat dilakukan oleh SEM yang berbasis kovarian karena akan menjadi unidentified model. Langkah-langkah PLS adalah (1)merancang model structural atau inner model. Inner model yang kadang disebut juga (inner relation, structural model dan subtantive theory) adalah menggambarkan hubungan antar variabel laten berdasarkan pada substantive theory (Ghozali, 2011). (2)merancang model pengukuran atau outer model. Outer model sering juga disebut (outer relation atau measurenment model) mendefinisikan bagaimana setiap blok indikator berhubungan dengan variabel laten (Ghozali, 2011).(3)merancang kontruksi diagram jalur. (4)konversi diagram jalur ke sistem persamaan. (5)melakukan estimasi atau pendugaan parameter.

Pendugaan parameter dilakukan untuk menghitung data variabel laten. Metode pendugaan parameter (estimasi) di dalam PLS adalah metode kuadrat terkecil (least square methods). Proses perhitungan dilakukan dengan cara iterasi, dimana iterasi akan berhenti jika telah tercapai kondisi kenvergen. Estimasi parameter yang didapat dengan PLS dapat dikategorikan menjadi tiga yaitu (Ghozali, 2011), yaitu (1)weight estimate yang digunakan untuk menciptakan skor variabel laten. (2)path estimate (estimasi jalur) yang menghubungkan variabel laten dan antara variabel laten dan blok indikatornya (loading). (3)means dan lokasi parameter (nilai konstanta regresi) untuk indikator dan variabel laten. (4)goodness of fit dibagi menjadi dua yaitu outer model dan inner model. (5)evaluasi model dibagi menjadi dua yaitu outer model dan inner model. (6)model pengukuran atau outer model, (7)pengujian hipotesis (resampling bootstraping).

\section{HASIL DAN PEMBAHASAN \\ Evaluasi Model Pengukuran}

Sebelum melakukan pengujian hipotesis penelitian pada evaluasi model Struktural penelitian, terlebih dahulu dilakukan evaluasi terhadap model pengukuran dalam penelitian. Evaluasi ini dilakukan dengan melakukan uji validitas konvergen, validitas diskriminan, dan uji reliabilitas.

\section{Uji Validitas Konvergen (Outer Loading)}

Pemeriksaan pertama model pengukuran adalah uji validitas konvergen (convergent validity), yang dapat dilihat dari nilai Outer loading atau loading faktornya. Kriteria yang digunakan adalah nilai Outer Loadingnya $\geq 0,5$. Jika terdapat indikator yang memiliki nilai outer loading $<0,5$ maka indikator tersebut harus dikeluarkan dari model yang tersaji pada Tabel 1. 
Tabel 1

Hasil Uji Validitas Konvergen Model Pengukuran

\begin{tabular}{|c|c|c|c|}
\hline Indikator & Tingkat Kecemasan & Indikator & Persepsi Pengendara \\
\hline $\mathrm{X} 1$ & 0,704 & Y1 & 0,800 \\
\hline $\mathrm{X} 2$ & 0,481 & $\mathrm{Y} 2$ & 0,349 \\
\hline $\mathrm{X} 3$ & 0,269 & Y3 & 0,401 \\
\hline $\mathrm{X} 4$ & 0,197 & Y4 & 0,577 \\
\hline X5 & 223 & Y5 & 0,051 \\
\hline $\mathrm{X} 6$ & 0,453 & Y6 & 0,242 \\
\hline $\mathrm{X} 7$ & 0,279 & Y7 & 0,440 \\
\hline $\mathrm{X} 8$ & $-0,179$ & Y8 & 0,181 \\
\hline $\mathrm{X} 9$ & 0,297 & Y9 & 0,146 \\
\hline X10 & 0,303 & Y10 & $-0,128$ \\
\hline $\mathrm{X} 11$ & 0,216 & Y11 & $-0,076$ \\
\hline $\mathrm{X} 12$ & 0,421 & Y12 & $-0,113$ \\
\hline $\mathrm{X} 13$ & 0,638 & Y13 & 0,690 \\
\hline $\mathrm{X} 14$ & 0,634 & Y14 & 0,492 \\
\hline $\mathrm{X} 15$ & 0,286 & Y15 & 0,817 \\
\hline \multirow[t]{4}{*}{ X16 } & 0,748 & Y16 & 0,746 \\
\hline & & Y17 & 0,633 \\
\hline & & Y18 & 0,665 \\
\hline & & Y19 & 0,582 \\
\hline
\end{tabular}

Berdasarkan Tabel 1 di atas, dapat diketahui bahwa untuk variabel Tingkat Kecemasan (X) hanya terdapat dua indikator yang memiliki outer loading $\geq 0,7$. Sedangkan untuk variabel Persepsi Pengendara (Y) hanya terdapat tiga indikator yang memiliki outer loading $\geq 0,7$. Karena terdapat indikator-indikator yang tidak valid dalam model awal, maka model divalidasi ulang, sehingga diperoleh hasil sebagai berikut:

Tabel 2.

Hasil Uji Validitas Konvergen Model Pengukuran Setelah Indikator Tidak Valid Dikeluarkan dari Model

\begin{tabular}{|c|c|c|c|}
\hline Indikator & Tingkat Kecemasan & Indikator & Persepsi Pengendara \\
\hline $\mathrm{X} 1$ & 0,897 & Y1 & 0,899 \\
\hline $\mathrm{X} 16$ & 0,833 & Y15 & 0,901 \\
\hline & & Y16 & 0,846 \\
\hline
\end{tabular}

\section{Uji Validitas Diskriminan}

Pemeriksaan selanjutnya yaitu uji validitas diskriminan (discriminant validity) ynag berhubungan dengan prinsip bahwa variabel pengukur dengan variabel laten (konstruk) yang berbeda seharusnya tidak berkorelasi dengan tinggi (Ghozali, 2012). Ada beberapa cara untuk melihat validitas diskriminan, yaitu:

a. Nilai Cross-loading Faktor Utama

Validitas diskriminan dapat dilihat dari nilai cross-loading yang menggambarkan korelasi antara suatu indikator dengan konstruknya dan dengan konstruk (variabel laten) lainnya. Jika korelasi konstruk dengan indikatornya lebih tinggi dari korelasi dengan konstruk lainnya, maka hal ini menunjukkan konstruk laten tersebut mampu memprediksi indikatornya dengan lebih baik daripada konstruk lainnya (Yamin, 
2011). Berikut adalah hasil uji validitas diskriminan untuk masing-masing indikator tersaji pada Tabel 3.

Tabel 3.

Hasil Uji Validitas Diskriminan Berdasarkan Nilai Cross-loading

\begin{tabular}{ccc}
\hline Indikator & Tingkat Kecemasan & Persepsi Pengendara \\
\hline X1 & $\mathbf{0 , 8 9 7}$ & 0,465 \\
\hline X16 & $\mathbf{0 , 8 3 3}$ & 0,371 \\
\hline Y1 & 0,464 & $\mathbf{0 , 8 9 9}$ \\
\hline Y15 & 0,470 & $\mathbf{0 , 9 0 1}$ \\
\hline Y16 & 0,333 & $\mathbf{0 , 8 4 6}$ \\
\hline
\end{tabular}

Berdasarkan Tabel 3 di atas, diketahui bahwa setiap variabel indikator memiliki korelasi yang lebih tinggi dengan konstruknya dibanding dengan konstruk (variabel lainnya).

\section{b. Nilai Rasio Heterotrait-Monotrait (HTMT)}

Prosedur kedua uji validitas konvergen dapat dilakukan dengan metode Rasio HeterotraitMonotrait (HTMT), dimana nilai rasio < 0,85 maka variabel indikator dikatakan valid diskriminan (Henseler, 2015). Berdasarkan Tabel 4 di atas, diketahui bahwa nilai rasio Heterotrait-Monotrait < 0,85 sehingga dikatakan memenuhi validitas diskriminan.

Tabel 4.

Hasil Uji Validitas Diskriminan Berdasarkan Nilai Rasio Heterotrait-Monotrait

\begin{tabular}{ccc}
\hline Uji validitas & Tingkat Kecemasan & Persepsi Pengendara \\
\hline Tingkat Kecemasan & & \\
\hline Persepsi Pengendara & 0,624 & \\
\hline
\end{tabular}

3. Uji Reliabilitas

Setelah pemeriksaan validitas telah terpenuhi, tahapan selanjutnya yaitu pemeriksaan reliabilitas variabel laten (konstruk). Pemeriksaan ini dapat dilakukan dengan melihat nilai reliabilitas komposit (composite reliability) dan nilai rata-rata varians diekstrak (AVE)nya. Nilai reliabilitas komposit yang diterima harus lebih besar 0,70 dan nilai AVE harus lebih besar dari 0,50 (Ghozali, 2012).

Tabel 5.

Hasil Uji Reliabilitas Komposit

\begin{tabular}{ccc}
\hline Variabel & Reliabilitas Komposit & Rata-Rata Varians Dieskstrak (AVE) \\
\hline Tingkat Kecemasan & 0,856 & 0,749 \\
\hline Persepsi Pengendara & 0,913 & 0,779 \\
\hline
\end{tabular}

Tabel 5 di atas diketahui bahwa semua konstruk memiliki nilai reliabilitas komposit $>0,70$ dan nilai AVE $>0,50$. Sehingga variabel indikatornya dapat dikatakan konsisten dalam mengukur variabel latennya (konstruknya).

\section{Evaluasi Model Struktural (Inner Model)}

1. Uji Konstruk Signifikansi Outer-loading

Setelah tahap evaluasi model pengukuran dilakukan, tahap selanjutnya adalah untuk lebih memastikan bahwa model reflektif valid dan layak dipercaya sebagai konstruk yang 
mampu memberikan informasi yang baik, yang dapat diketahui dengan melihat uji signifikansi pada konstruk outer-loadingnya. Hasil uji tersebut disajikan pada Tabel 6.

Tabel 6. IUji Konstruk Signifikansi Outer-loading

\begin{tabular}{ccccc}
\hline Variabel & Parameter & Standar Deviasi & $\mathrm{T}_{\text {Hitung }}$ & Signifikansi \\
\hline X1 <- Tingkat Kecemasan & 0,897 & 0,041 & 21,737 & 0,000 \\
\hline X16 <- Tingkat Kecemasan & 0,833 & 0,090 & 9,290 & 0,000 \\
\hline Y1 <- Persepsi Pengendara & 0,899 & 0,023 & 38,893 & 0,000 \\
\hline Y15 <- Persepsi Pengendara & 0,901 & 0,047 & 19,161 & 0,000 \\
\hline Y16 <- Persepsi Pengendara & 0,846 & 0,052 & 16,142 & 0,000 \\
\hline
\end{tabular}

Tabel 6 dapat diketahui bahwa semua konstruk memiliki nilai signifikansi < 0,05 (tingkat kepercayaan 95\%), sehingga dapat dinyatakan bahwa seluruh konstruk adalah valid dan menyakinkan peneliti untuk dapat diteruskan ke proses analisis model Struktural (innermodel).

\section{Uji Hipotesis Penelitian}

Tahap selanjutnya yaitu melakukan pengujian hipotesis yaitu, analisis tingkat hubungan kausal antar konstruk dan menetapkan signifikansinya ( $P$-Value). Hasil perhitungan dapat dilihat pada Tabel 7 berikut:

Tabel 7.

Uji Hipotesis Penelitian

\begin{tabular}{ccccc}
\hline Variabel & Parameter & Standar Deviasi & THitung $_{\text {Handikansi }}$ & Signifiks \\
\hline $\begin{array}{c}\text { Tingkat Kecemasan -> Persepsi } \\
\text { Pengendara }\end{array}$ & 0,487 & 0,098 & 4,971 & 0,000 \\
\hline
\end{tabular}

Tabel 7 diketahui bahwa nilai estimasi parameter untuk pengaruh Tingkat Kecemasan terhadap Persepsi Pengendara sebesar 0,487 dengan nilai signifikansi sebesar 0,000 lebih kecil dari 0,05. Dengan kata lain dapat dikatakan bahwa, terdapat pengaruh positif tingkat kecemasan terhadap persepsi pengendara di saat New Normal (H1 diterima). Diagram Jalur (Path Diagram) hasil estimasi Parameter pengaruh Tingkat Kecemasan terhadap Persepsi Pengendara dapat dilihat juga pada Gambar 1.

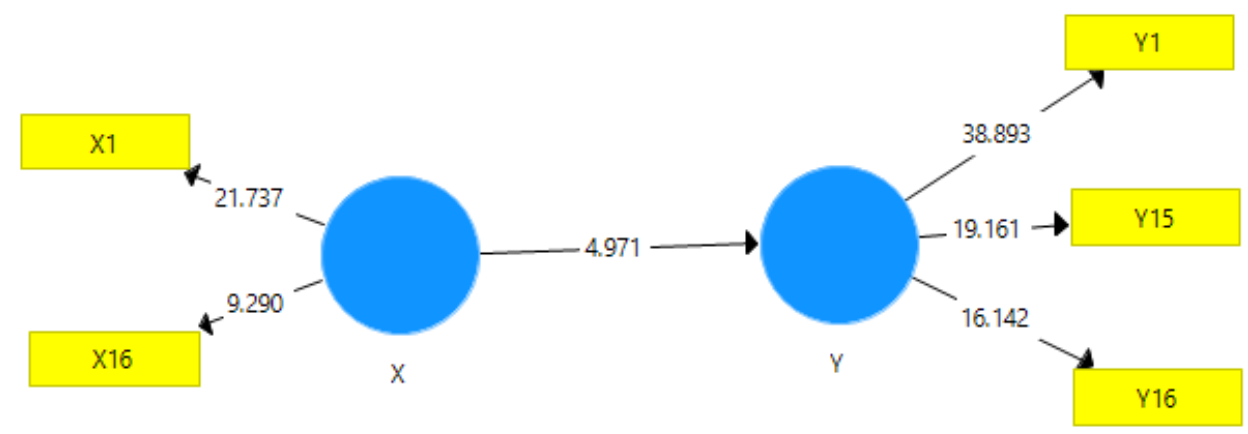

Gambar 1. Path Diagram Model Penelitian

3. Evaluasi Inner Model

Untuk menilai model secara keseluruhan, digunakan beberapa cara, yakni dengan melihat nilai koefisien determinasinya $\left(\mathrm{R}^{2}\right)$, nilai Effect Sizenya $\left(f^{2}\right)$, dan kriteria goodness of fit 
menggunkan Nilai Standardized Root Mean Square Residual (SRMR) dan Normed Fit Index (NFI). Hasil perhitungannya dapat dilihat sebagai berikut.

a. Berdasarkan Nilai Koefisien Determinasi $\left(\mathrm{R}^{2}\right)$

Berdasarkan Tabel 8 diketahui nilai $\mathrm{R}^{2}$ persepsi pengendara sebesar 0,238 ; begitupula dengan nilai Adjusted $\mathrm{R}^{2}$ nya yakni sebesar 0,226. Dengan kata lain model struktural penelitian ini berdasarkan nilai $\mathrm{R}^{2}$ tergolong lemah, seperti yang direkomendasikan oleh Sarstedt, Ringle dan Hair (2011: 145), yang mengemukakan bahwa nilai $\mathrm{R}^{2}$ pada variabel laten endogen sebesar 0,75 termasuk dalam kategori tinggi (substansial); 0,50 termasuk dalam kategori sedang (moderate); dan nilai 0,25 termasuk dalam kategori lemah (weak).

Tabel 8.

Evaluasi Model Struktural Berdasarkan Nilai $\mathrm{R}^{2}$

\begin{tabular}{ccc}
\hline Evaluasi Model Struktural & $\mathrm{R}^{2}$ & Adjusted $\mathrm{R}^{2}$ \\
\hline Persepsi Pengendara & 0,238 & 0,226 \\
\hline
\end{tabular}

b. Berdasarkan Effect Size $\mathrm{f}^{2}$

Selain nilai $\mathbf{R}^{2}$, kriteria lain yang dapat digunakan adalah nilai effect size $f^{2}$. Hasil perhitungan dapat dilihat pada Tabel 9. Tabel 9 diketahui nilai effect size $f^{2}$ tingkat kecemasan terhadap persepsi pengendara sebesar 0,312. Dengan kata lain model struktural penelitian ini berdasarkan nilai effect size $f^{2}$ tergolong sedang (moderate), dimana Vinzi, dkk. (2010) menuliskan bahwa 0,02 (pengaruh variabel laten eksogen lemah); 0,15 (pengaruh variabel laten ekso-gen moderat), dan 0,35 (pengaruh variabel laten eksogen kuat).

Tabel 9.

Evaluasi Model Struktural Berdasarkan Nilai Effect Size $f^{2}$

\begin{tabular}{ccc}
\hline $\begin{array}{c}\text { Evaluasi Model } \\
\text { Struktural }\end{array}$ & Tingkat Kecemasan & Persepsi Pengendara \\
\hline Tingkat Kecemasan & & \\
\hline Persepsi Pengendara & 0,312 \\
\hline
\end{tabular}

c. Goodness of Fit Model

Selain kriteria $\mathrm{R}^{2}$ dan effect size $f^{2}$, kriteri goodness of fit (GoF) model struturak penelitian dapat juga dilihat berdasarkan nilai Standardized Root Mean Square Residual (SRMR) dan Normed Fit Index (NFI). Nilai SRMR dan NFI ini digunakan untuk mengukur sejauhmana model struktural yang dibuat peneliti benar-benar fit atau tidak. Dimana hasil perhitungannya dapat dilihat pada Tabel 10. Garson (2016) menuliskan bahwa nilai SRMS direkomendasikan kurang dari 0,08. Namun kurang dari 0,10 juga masih dianggap fit. Berdasarkan Tabel 10 nilai SRMR model struktural penelitian sebesar $0,087<0,1$; sehingga model dianggap fit. Begitupula dengan nilai NFI, semakin nilai NFI mendekati 1, maka model struktural dianggap semakin baik (Nabilah, dkk, 2020:152).

Tabel 10.

Evaluasi Model Struktural Berdasarkan Nilai Standardized Root Mean Square Residual (SRMR) dan Normed Fit Index (NFI)

\begin{tabular}{ccc}
\hline Evaluasi Model Struktural & Model Saturated & Model Estimasi \\
\hline SRMR & 0,087 & 0,087 \\
\hline NFI & 0,721 & 0,721 \\
\hline
\end{tabular}




\section{Analisis Karakteristik Pengendara}

Analisis karakteristik pengendara diidentifikasi dengan tujuan untuk mengetahui preferensi para pengendara bagaimana mereka berperilaku mengendarai di masa pandemik ini. Dari Gambar 3, dapat mewakili preferensi para pengendara setuju bahwasanya mereka merasa mengalami gangguan emosi pada kondisi new normal ini (variabel X1) dan merasa cemas apabila terdapat penumpang yang tidak mengenakan masker (variabel X16).

Adanya analisis karakteristik pengendara tersebut, para pengendara sadar bahwa mematuhi protokol kesehatan itu sangat penting. Kesadaran tersebut itulah yang akan membuat persepsi para pengendara terbentuk, sehingga risiko penularan virus Covid-19 ini akan kecil. Apabila mereka mematuhi protokol kesehatan seperti mengenakan masker, rajin menggunakan hand sanitizer, dan selalu mengenakan sarung tangan, mereka akan berkendara tanpa perlu adanya kecemasan yang berlebihan.
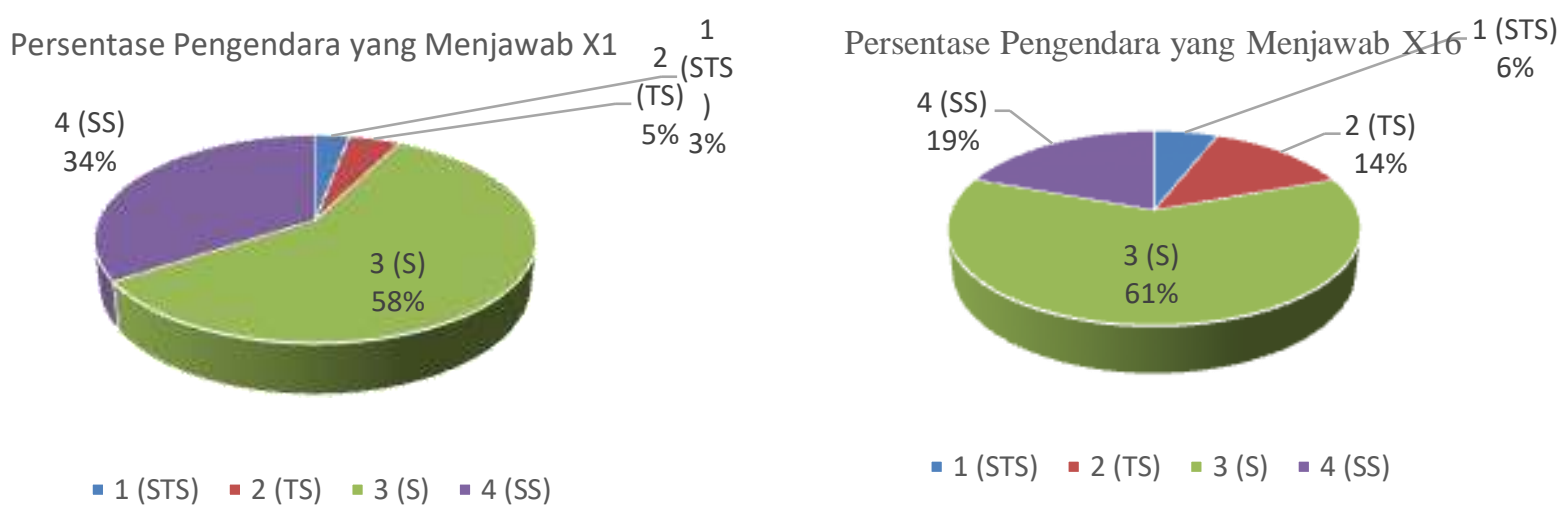

Gambar 3. Persentase Pengendara Menjawab Variabel X1 dan X16

\section{Analisis Perilaku Pengendara}

Penelitian ini dilakukan untuk mengetahui tingkat kecemasan pengemudi motor terhadap persepsi berpengendara ditengah pandemi saat ini. Obyek peneltian ini dilakukan kepada pengemudi ojek online yaitu PT. Gojek Indonesia. Berdasarkan dari hasil kuesioner yang telah dibagikan telah didapatkan data jika kecemasan berpengaruh signifikan dan arahnya postif. Hal ini menunjukkan sesuai dengan $\mathrm{H} 1$ yang dimana terdapat hubungan positif antara tingkat kecemasan dengan persepsi pengendara di saat new normal ini. Pada hasil perhitungan hubungan antara tingkat kecemasan terhadap persepsi pengendara mendapatkan hasil nilai signifikansi sebesar 0,000 dan nilai parameternya 0,487 . Hasil ini menunjukan jika tingkat kecemasan berpengaruh positif dan signifikan terhadap persepsi pengendara motor ojek online yang dimana merupakan pengemudi dari perusahan PT. Gojek Indonesia.

Hasil dari kuesioner yang telah dibagikan telah ditemukan jika para pengendara dari segi emosi cukup terkendali. Ini didukung dengan hasil pada item pertanyaan "Saya mengalami gangguan emosi akibat adanya covid dalam 2 minggu terakhir" banyak yang memilih jawaban tidak setuju sejumlah 29 dan sangat tidak setuju 19. Data ini menunjukan para pengendara mampu mengendalikan emosinya saat berkendara ditengah pandemi saat ini. Pada item pertanyaan "Saya merasa cemas apabila berinteraksi dengan penumpang apabila tidak mengenakan masker" banyak responden yang menjawab setuju sejumlah 45 dan sangat setuju 15. Ini menunjukan jika para pengendara ada perasaan cemas dikarenakan penumpang yang tidak memakai masker. Perasaan cemas ini menandakan jika para pengendara cukup waspada dalam berkendara ditengah pandemi saat ini. 
Variabel dependen persepsi pengendara pada item pertanyaan "Saya merasa tenang karena dengan memakai masker saat berhenti di lampu merah" banyak responden yang menjawab setuju sejumlah 32 dan sangat setuju sejumlah 37. Hal ini menunjukan jika responden dalam berkendara tidak ada rasa ketakutan ditengah pandemi saat ini. Ini membuat para pengendara ojek online bisa fokus dalam berkendara karena merasa tenang dalam berkendara ditengah pandemi saat ini. Pengendara yang tenang dalam berkendara akan dapat meminimalkan resiko kecelakaan saat berkendara. Pada item pertanyaan "Saya selalu membawa sarung tangan (gloves)" responden banyak memilih jawaban setujuh sejumlah 36, sedangkan pada item pertanyaan "Saya selalu membawa dan memakai hand sanitizer" responden banyak memilih jawaban sangat setujuh sejumlah 40. Ini menunjukan jika para responden mengedepakan protokol kesehatan ketika keluar rumah dan terutama dalam berkendara ditengah pandemi saat ini.

Berdasarkan hasil kuesioner yang telah disebar dapat menjelaskan jika para pengendara memikili rasa tenang ketika dalam berkendara dan memiliki rasa emosi yang stabil dalam berkendara dalam era pandemi saat ini. Pengendara yang tenang dalam berkendara membuat lebih fokus dalam berkendara, sehingga resiko kecelakaan dalam berkendara dikarenakan faktor tidak fokus bisa ditekan. Namun tidak dipungkiri jika para pengendara memiliki rasa cemas jika para penumpang tidak memakai masker ketika berkendara. Para pengendara meminimalkan resiko tertular jika ada penumpang yang tidak diketahui sebelumnya memiliki gejala covid-19 dengan memakai sarung tangan untuk meminimalkan kontak secara langsung jika tidak sengaja ada kontak tangan. Pengendara jika tidak lupa menyediakan hand sanitazer untuk digunakan dalam waktu tertentu untuk menimalkan adanya bakteri atau virus yang menempel ditangan. Responden menunjukan jika memiliki rasa cemas tetapi untuk mengurangi kecemasan itu dengan menerapkan ajuran dari pemerintah untuk menerapkan protokoler kesehatan dengan disiplin. Persepsi pengendara yang baik ini secara tidak langsung mampu ikut menekan laju pertumbuhan pasien covid-19 di Bali dikarenakan para pengendara ojek online mampu menerapkan protokoler kesehatan dengan baik.

\section{SIMPULAN}

Karakteristik pengendara berdasarkan jenis kelamin dalam era new normal di Bali sebanyak $87 \%$ pria menyetujui bahwa mereka kecenderungan mengalami gangguan emosi dan sisanya $13 \%$ pengendara wanita. Rasa kecemasan pun dialami $15 \%$ wanita apabila ada penumpang tidak mengenakan masker dan sisanya $85 \%$ pengendara pria. Perasaan tenang pun juga dialami $86 \%$ pria apabila mengenakan masker saat berhenti di lampu lalu lintas dan sisanya $14 \%$ pengendara wanita. Sedangkan pengendara pria sebesar $88 \%$ menyatakan bahwa mereka membawa sarung tangan dan sisanya pengendara wanita sebesar $12 \%$. Begitu juga pengendara wanita sebanyak $16 \%$ selalu memakai hand sanitizer dan sisanya pengendara pria sebesar $84 \%$. Hubungan antara tingkat kecemasan terhadap persepsi pengendara dalam berkendara memiliki hubungan positif siginifikan. Ini menunjukan jika rasa cemas dapat membentuk persepsi pengendara.

\section{DAFTAR PUSTAKA}

Engel, James F.Roger Blackwell, Paul W. Miniard. 1994. Perilaku Konsumen. Jilid kesatu, edisi keenam. Jakarta: Binarupa Aksara.

Garson, G. David. (2016). Partial Least Squares: Regression \& Structural Equation Models. School of Public \& International Affairs: North Carolina State University. 
Ghozali, I. dan Latan, H. (2012), Partial Least Square: Konsep, Teknik dan Aplikasi SmartPLS 2.0 M3. Badan Penerbit Universitas Diponegoro: Semarang.

Nabilah, Z., Hermuningsih, S., dan Wiyono, G. (2020). Pengaruh Operating Leverage dan Likuiditas terhadap Nilai Perusahan dengan Struktur Model sebagai Variabel Intervening pada Perusahan Sektor Consumer Goods Industry yang Terdaftar di Bursa Efek Indonesia Tahun 2016-2018. Bisman, 3(2). h. 148 - 159.

Sarstedt, Marko, Ringle, Christian M., dan Hair, Joe F. (2011). PLS-SEM: Indeed a Silver Bullet. The Journal of Marketing Theory and Practice, 19(2), 139-152.

Shiina, et al. (2020). Relationship Beetwen Perception and Anxiety about COVID-19 Infection and Risk Behaviour for Spreading Infection: A National Survey in Japan. Brain, Behaviour, and Immunity - Health. Vol. 6-100101.

Stavrinos, et al (2020). Adolescent Driving Behaviour Before and During Restictions Related to COVID-19. Accident Analysis and Prevention. Vol. 144-105686.

Vinzi, V. E., Chin, W. W., Henseler, J., \& Wang, H. (2010). Handbook of Partial Least Squares. Series: Springer Handbooks of Computational Statistics. NY: Springer-Verlag. 